University of South Florida

DIGITAL COMMONS

@ UNIVERSITY OF SOUTH FLORIDA
Digital Commons @ University of

South Florida

$11-1-2004$

\title{
Rideshare/511 Signage in the U.S. and Canada
}

CUTR

Follow this and additional works at: https://digitalcommons.usf.edu/cutr_nctr

\section{Scholar Commons Citation}

CUTR, "Rideshare/511 Signage in the U.S. and Canada" (2004). Research Reports. 242.

https://digitalcommons.usf.edu/cutr_nctr/242

This Technical Report is brought to you for free and open access by the National Center for Transit Research (NCTR) Archive (2000-2020) at Digital Commons @ University of South Florida. It has been accepted for inclusion in Research Reports by an authorized administrator of Digital Commons @ University of South Florida. For more information, please contact digitalcommons@usf.edu. 
National Center Transit Resear

\section{Rideshare / 511 Signage in the U.S. and Canada}

Compiled by the National Center for Transit Research

October, 2004

National Center for

Transit Research

nter for search

\section{National Center for Transit Research}

Center for Urban Transportation Research University of South Florida

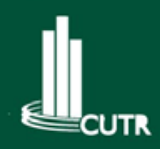




\section{State Road Signage (Alphabetized)}

\section{Alaska}

Alaska is currently working on an Invitation to Bid to install 511 Travel Info, Buckle Up and Scenic Byways signs in spring/summer 2005. Attached are the 511 Travel Info signs. There are 54 installed 511 Travel Info signs along major highways, at major highway intersections and within Anchorage (leaving the airport, leaving town, entering town). Smaller 511.Alaska.gov signs will be installed the following year (funding permitting) at ferry terminals, major parking lot areas.
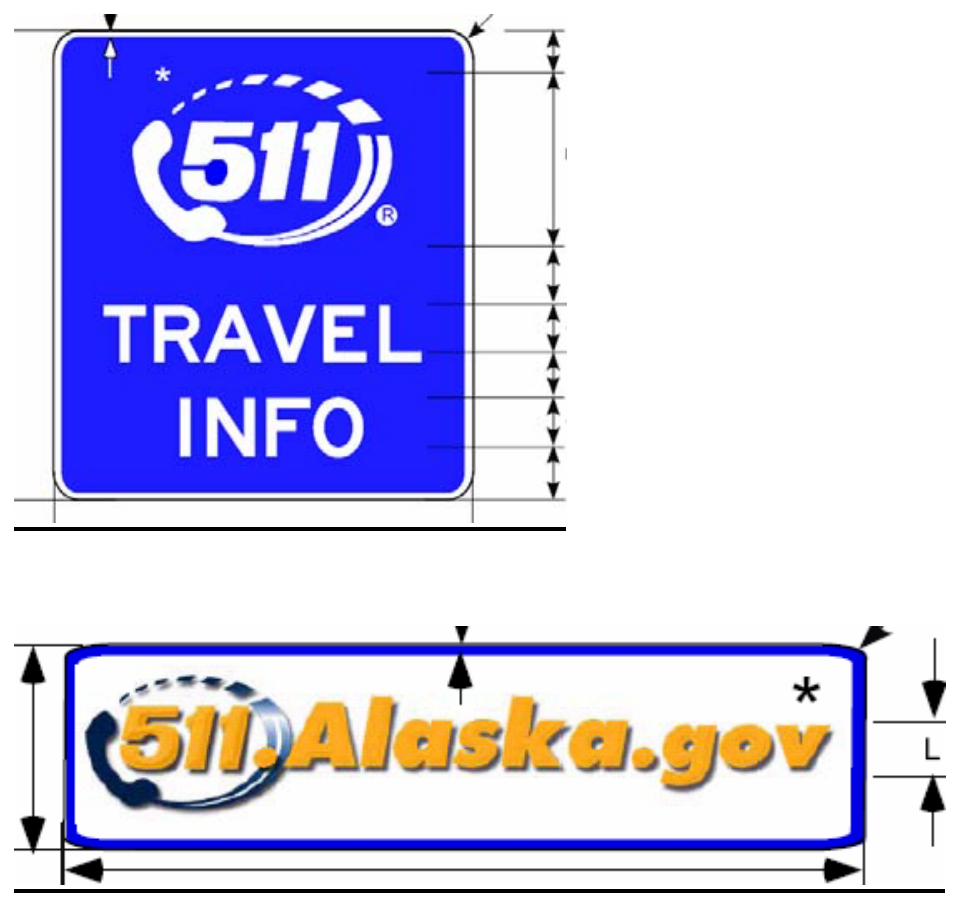


\section{Arizona}

To date, this is the only approved 511 sign used in Arizona The sign for carpools using 511 instead of local numbers will be developed in the near future. The new traveler info sign will include a logo. A sign WITHOUT the logo is attached for reference only.

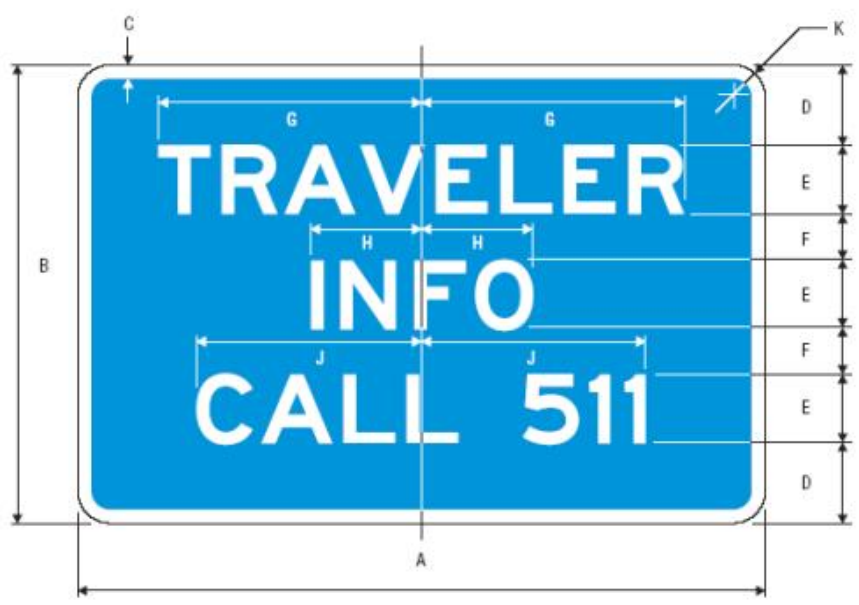

D12.5

\begin{tabular}{|c|c|c|c|c|c|c|c|c|c|}
\hline A & B & C & D & E & F & G & H & J & K \\
\hline 60 & 40 & 1.25 & 7 & $6 \mathrm{E}$ & 4 & 22.957 & 9.667 & VAR & 3 \\
\hline 80 & 50 & 1.25 & 7 & $8 \mathrm{E}$ & 6 & 30.603 & 12.909 & VAA & 3 \\
\hline 96 & 72 & 1.25 & 13 & $10 \mathrm{E}$ & 8 & 38.249 & 16.132 & VAR & 3 \\
\hline
\end{tabular}

COLORS: LEGEND -WHITE (RETROREFLECTIVE) BACKGROUND - BLUE (RETROREFLCTIVE)

3-67 


\section{California}

Below are some photos/drawings of the highway signs that are used in the Bay Area. In San Francisco rideshare calls are answered through 511, the 511 signs are the only ones in use, there are no specific rideshare signs. They have been used in the past, but now that the 511 system has been implemented, all the signs are being converted to the 511 signs.

These signs are used in the nine-county San Francisco Bay Area only (Alameda, Contra Costa, Marin, Napa, San Francisco, San Mateo, Santa Clara, Solano, Sonoma). Other regions within California may use different signs, as they might not have incorporated ridesharing into their 511 systems. For example, in Southern California (L.A. metropolitan region), the 1-866-RIDESHARE has been used. Therefore, their highway signs would either reflect this number or no number at all. They don't have a 511 system implemented in this area.
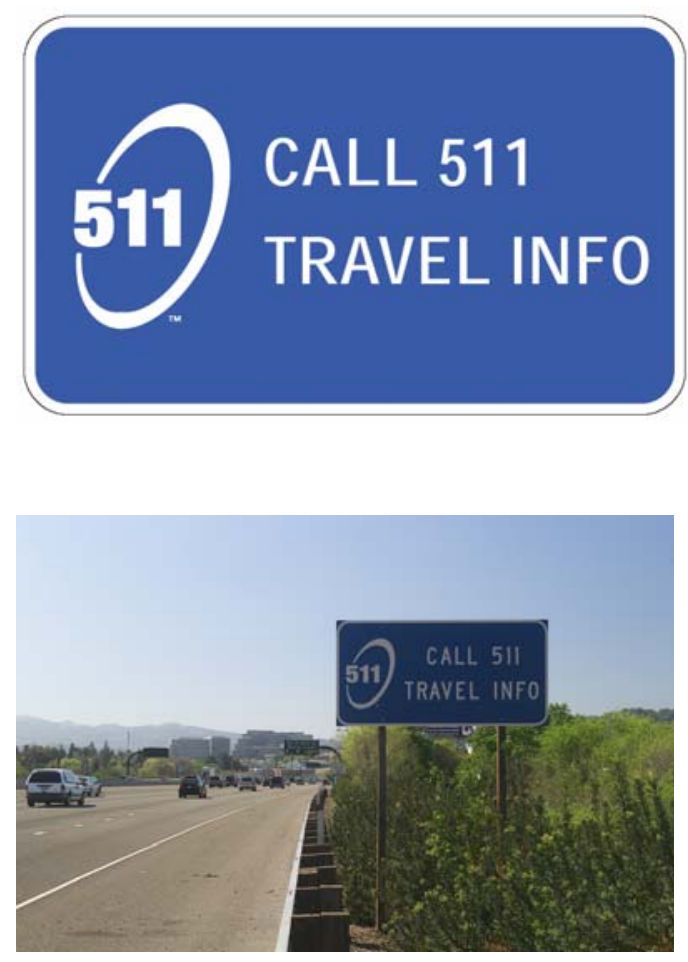


\section{Canada}

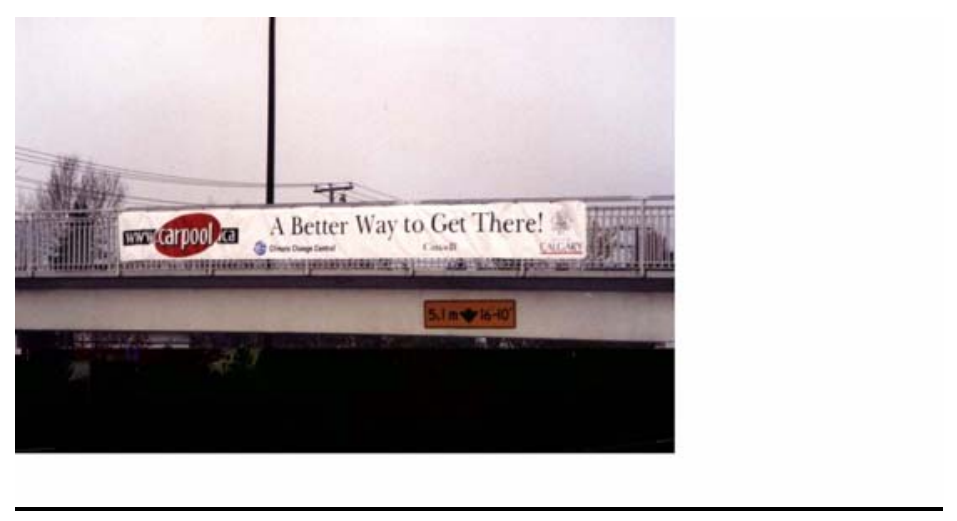

Below is a picture of signage currently used in the City of Calgary.

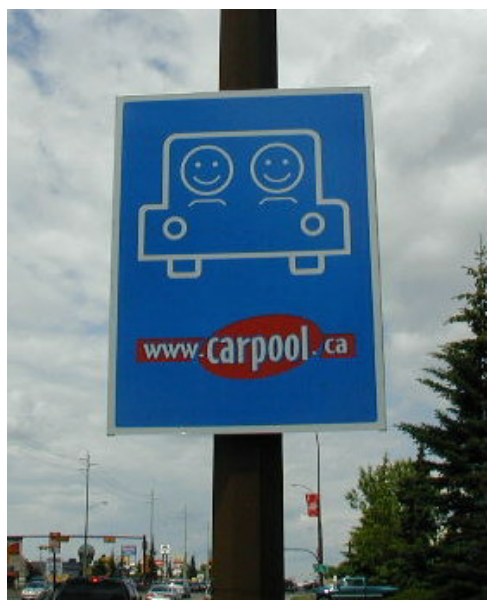




\section{Colorado}

Colorado DOT is at the beginning of the implementation of 511. Colorado will use the standard FHWA sign design http://www.its.dot.gov/511/511sign.htm\#511sign .

The logo of a commercial entity shall not be incorporated within the $\underline{\mathrm{D} 12-5}$ sign. The TRAVELER INFO CALL 511 sign shall have a white legend and border on a blue background.
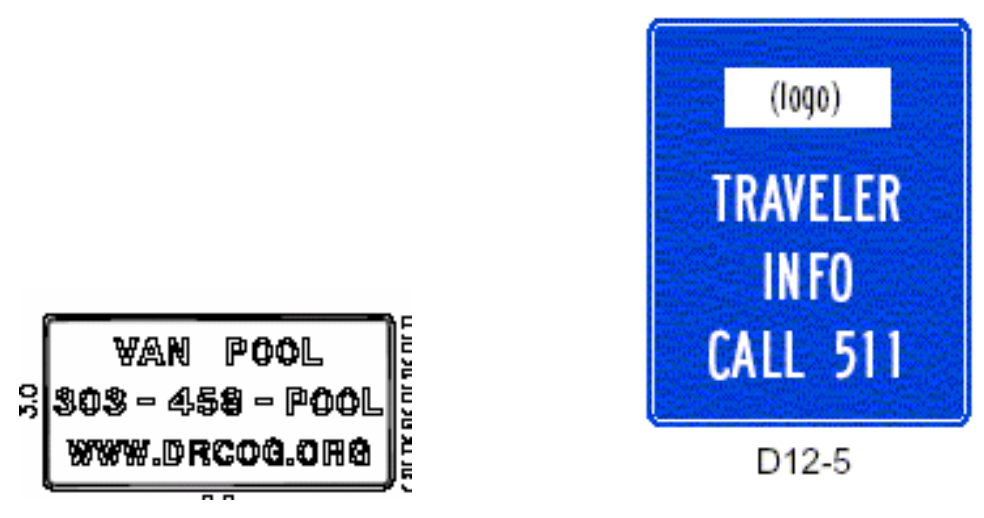


\section{Delaware}

Older signs (pre-RideShare Delaware) said 'Commuter Assistance'. Today, many are changed over to say Ridematch Assistance while still a few remain with Commuter Assistance, but all have the phone numbers on them. Citizens call for all sorts of things: how to get their car across country was big for a while, EZ Pass and construction information mostly, but also for the services provided - how to help them find a ride. 


\section{$\underline{\text { Florida }}$}

Here are some examples of commuter assistance and 511 signage currently used in Florida.
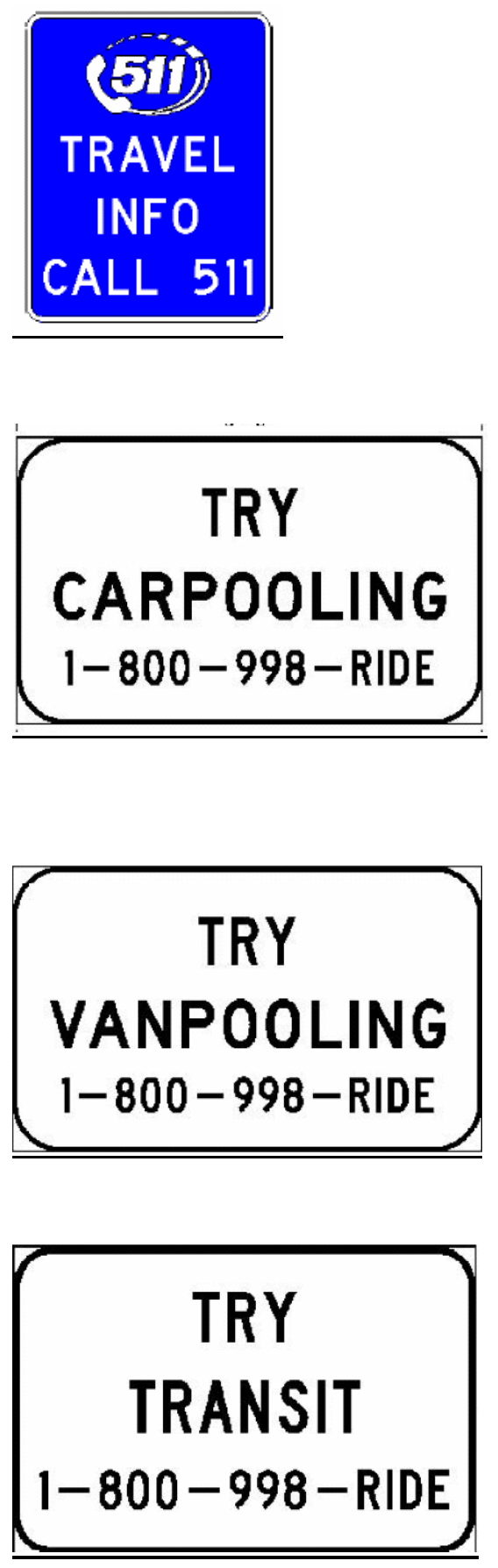


\section{Indiana}

Indiana does not currently have any statewide signage regarding carpool/transit/511 information. Local communities have some of their own signs but it is very limited. Some of these are the "Share the Ride" sign in northwest Indiana by Chicago and a 327RIDE carpool sign in the Indianapolis area. 


\section{Iowa}

Attached are pictures of the 511 sign used in Iowa and the rideshare sign that is used in the Des Moines area. Currently, the 511 signs are only installed on the Interstate system at the state borders and in advance of the rest areas, as well as in the rest areas.
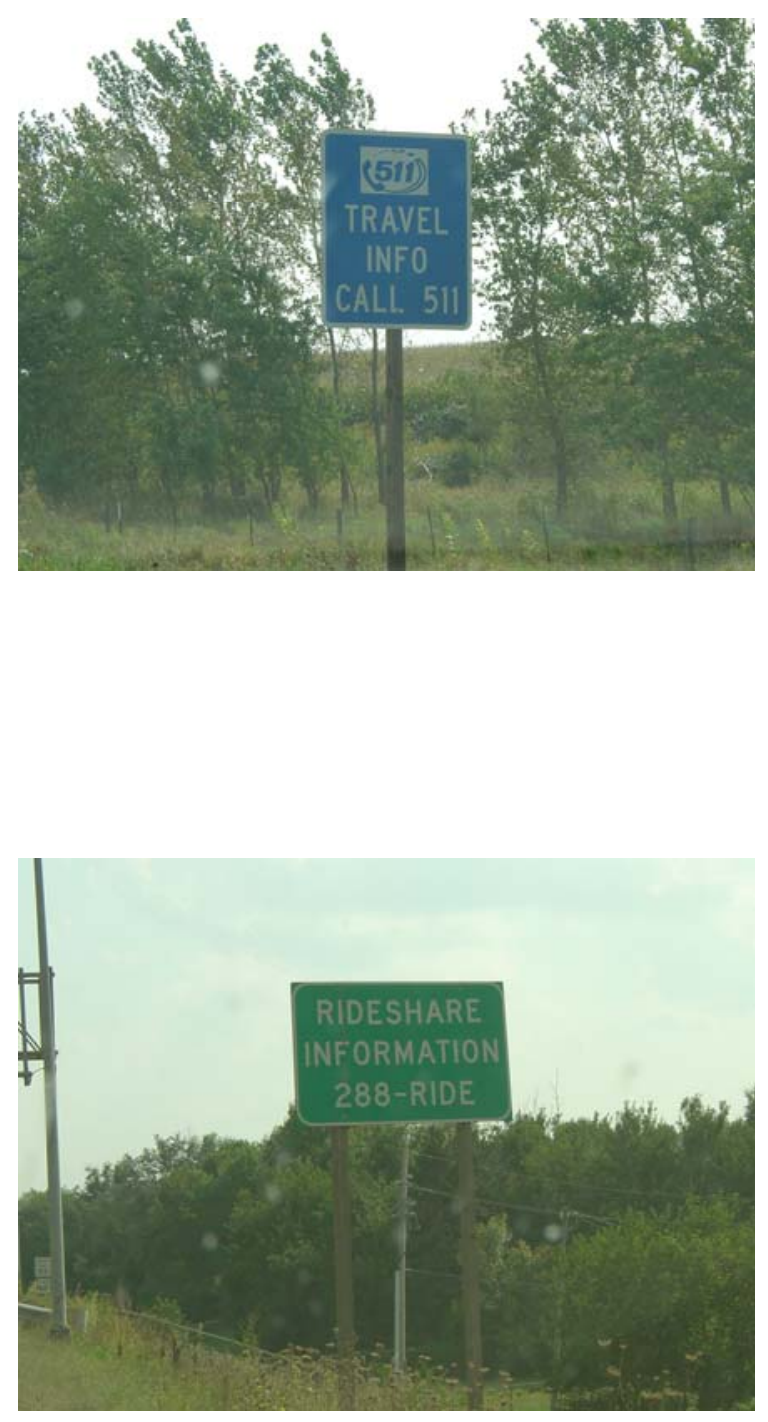


\section{Maine}

The Maine DOT and the Maine Turnpike are currently erecting hundreds of new highway signs across Maine to promote GO MAINE, the state's commuter services program. Highway signs have been and continue to be one of the top ways that commuters find out about the program.

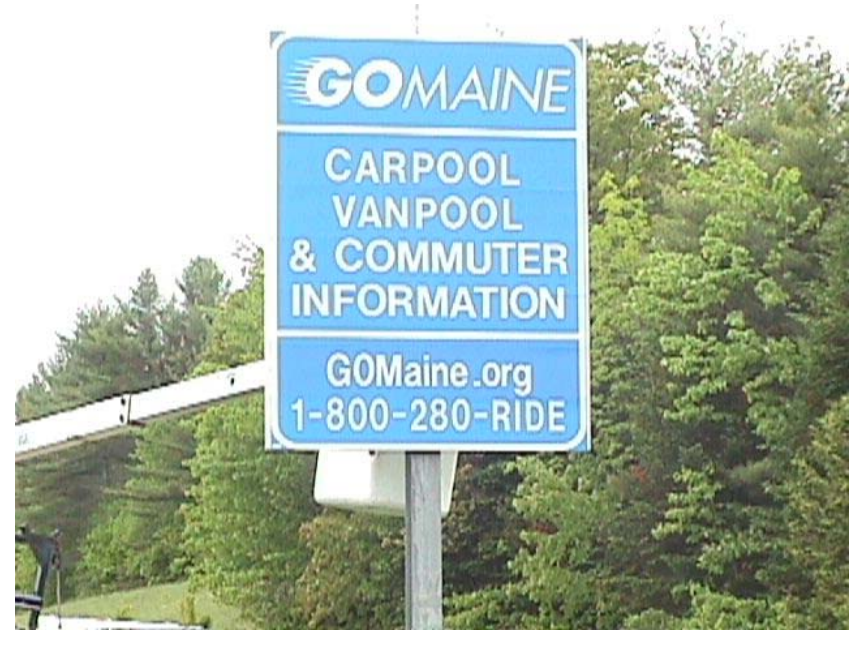




\section{Maryland}

Most of the highway signs in Maryland read: "Car/Vanpool Information".

The signs also list the phone number and recently some programs have added their web address. Maryland has found that the majority of calls received are generated through these highway signs. The signs are specific to each county program. Some programs have the county logo and others just have the verbiage on them. 


\section{$\underline{\text { Massachusetts }}$}

Here are some of the commuter assistance signs currently used in Massachusetts.
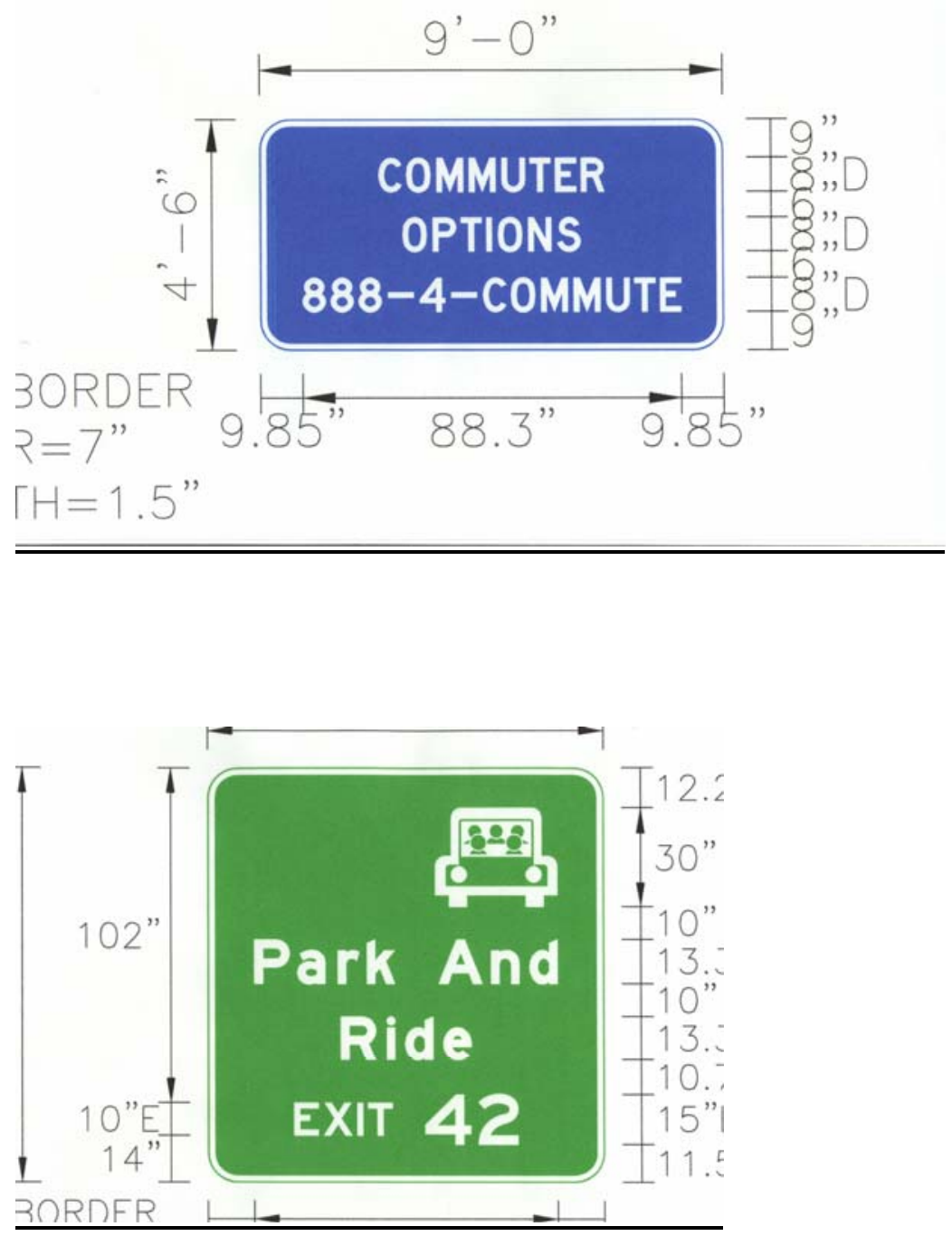

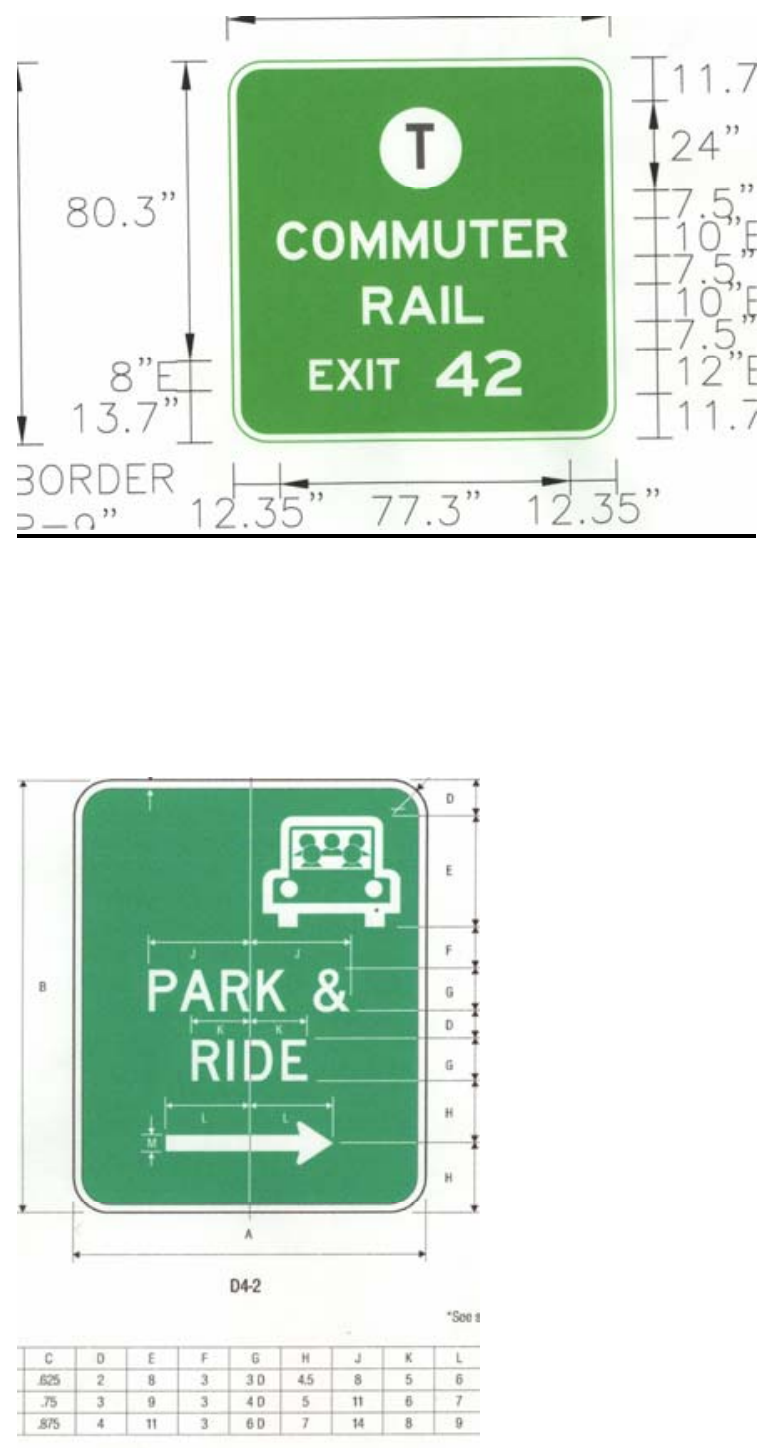

COLOAS: LEGEND - WIIE

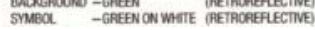




\section{$\underline{\text { Michigan }}$}

Here is a picture of the sign used in Southeast Michigan.

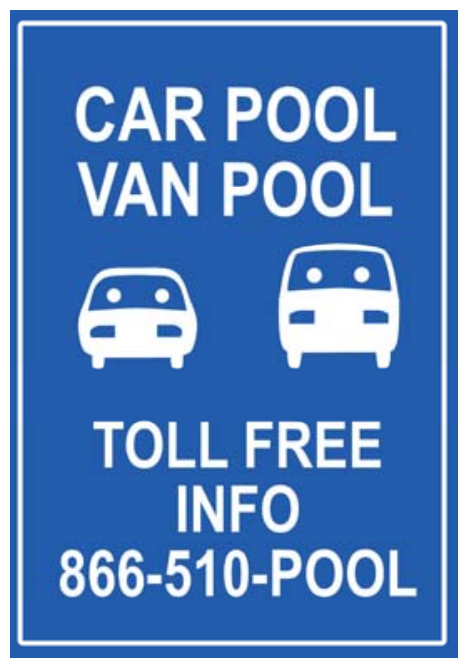




\section{Missouri}

In the St. Louis area, blue informational signing is provided for Ridesharing information. The verbiage is consistent with the rest of the state but the number is different. The "1-800 VIP RIDE" phone number is the contact number to RideFinders in Madison County Illinois. RideFinders is the St. Louis region's car pool authority that promotes car pooling in the region along with van pools.

At this time, there is not a dedicated 511 number for Missouri traffic information. The traffic information hotline is 1-888 511 4STL. Once the number is converted to 511, there may be a transit information on the hotline.

\section{RIDESHARE} 800-VIP-RIDE 


\section{New Mexico}

The signs in New Mexico are simple, blue background, white letters and say:

\section{RIDESHARE \\ 988-ride}

They are the centralized call center for information statewide.

New Mexico does not have 511 info calling at this time. 


\section{New York}

Below is a picture of the Rideshare Information Signage used by the Long Island Transportation Management (LITM), the Transportation TDM for Long Island, New York.

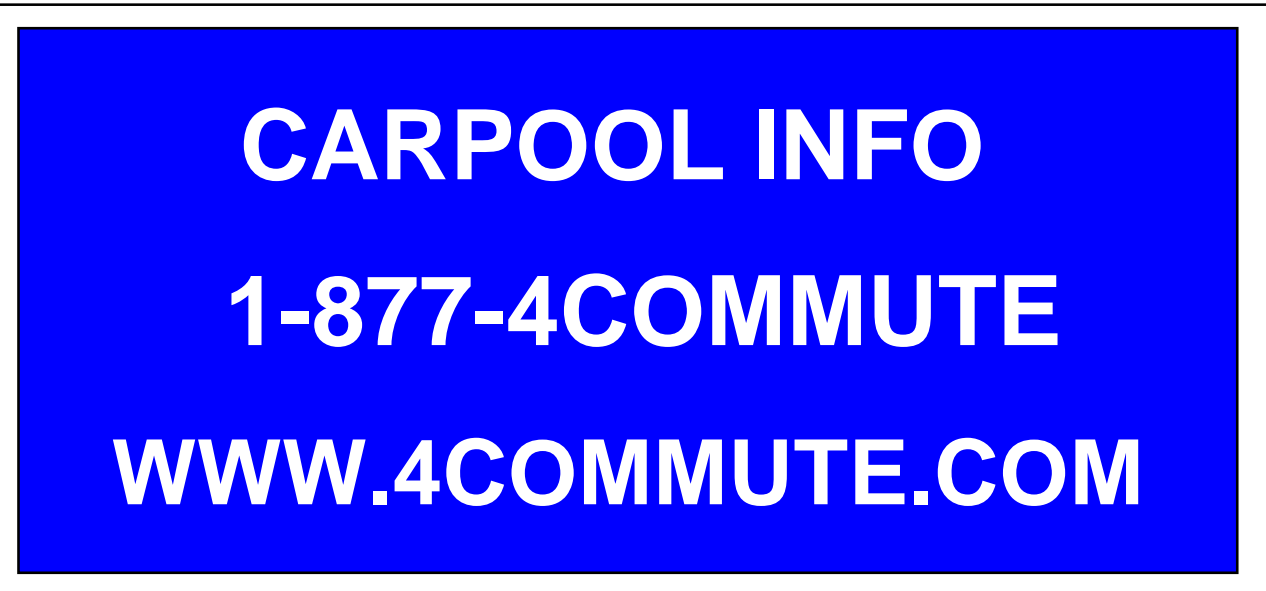




\section{North Carolina}

In the Triangle area of North Carolina, we there is one standard sign that promotes carpool, vanpool, and bus. It has the Triangle Transit Authority logo, and the phone number indicating that it is the information number for vanpool, carpool, and bus. There are currently over 100 of these signs up in a 3-county area. 


\section{Oklahoma}

Here are some signs currently used in Oklahoma. The Oklahoma DOT does not anticipate carpooling becoming a popular mode of commuting.
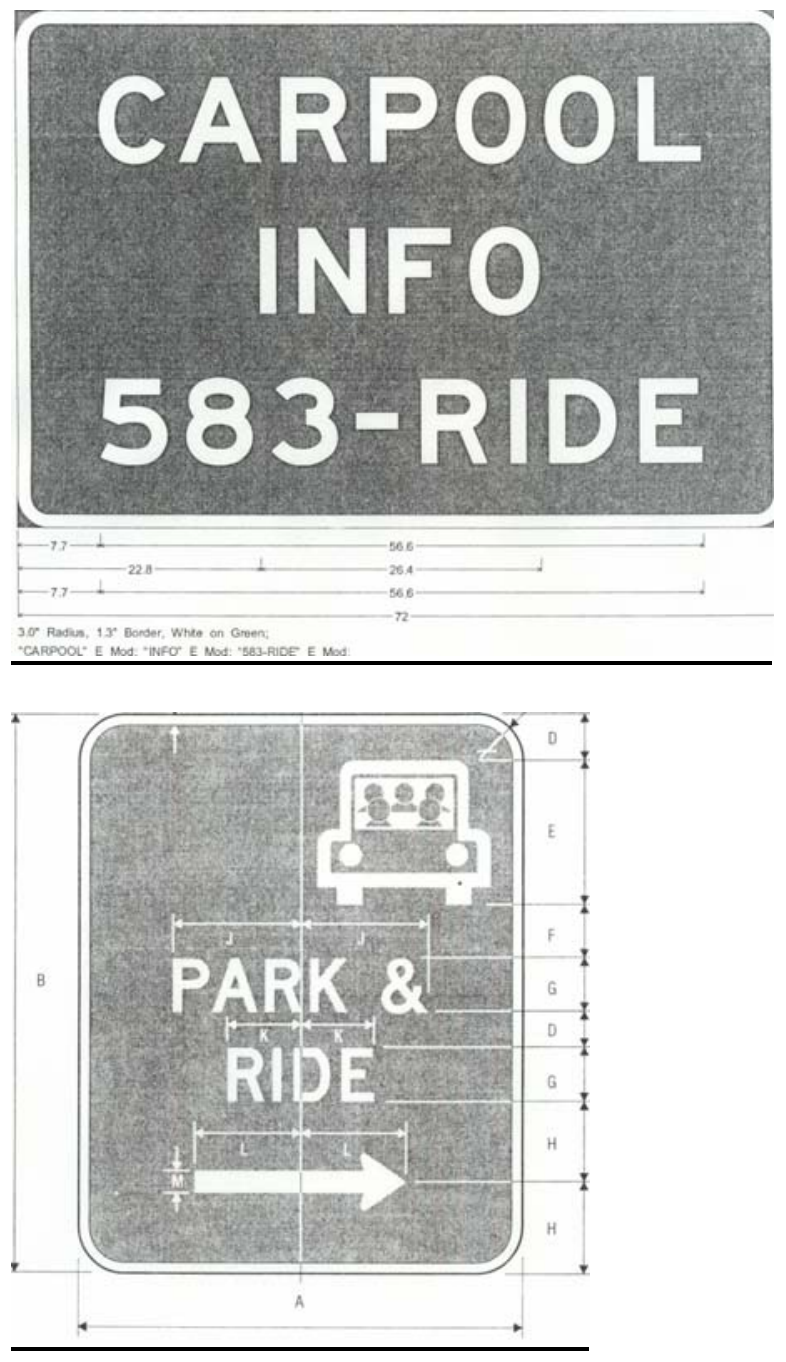

\begin{tabular}{|c|c|c|c|c|c|c|c|c}
\hline $\mathrm{C}$ & $\mathrm{D}$ & $\mathrm{E}$ & $\mathrm{F}$ & $\mathrm{G}$ & $\mathrm{H}$ & $\mathrm{J}$ & $\mathrm{K}$ & $\mathrm{L}$ \\
\hline 625 & 2 & 8 & 3 & $3 \mathrm{D}$ & 4.5 & 8 & 5 & 6 \\
\hline .75 & 3 & 9 & 3 & $4 \mathrm{D}$ & 5 & 11 & 6 & 7 \\
\hline 875 & 4 & 11 & 3 & $6 \mathrm{D}$ & 7 & 14 & 8 & 9 \\
\hline
\end{tabular}




\section{Pennsylvania}

Below is a picture of the Carpool/Vanpool sign currently being used in Pennsylvania. It is for the SW PA region which includes 10 counties.

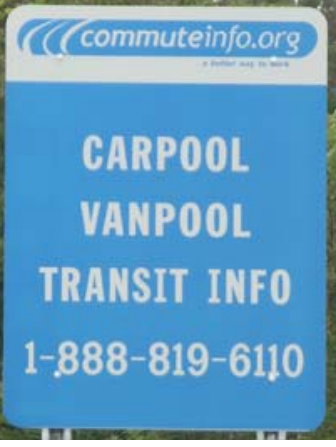




\section{Rhode Island}

Rhode Island has used the Park \& Ride signs in the past. The state has also used the AMTRAK symbol to direct motorists to the train station, which has appeared to have moderate effectiveness. There are no 511 signs installed at this time, however it will implement the program in December of this year. At that time, 511 signs will be installed.

\section{South Carolina}

This state does not provide this information on state road signs. 


\section{$\underline{\text { Tennessee }}$}

The 511 program is just starting in Tennessee and hasn't taken complete form yet; therefore, there are no signs connected with carpooling. According to the Design Department there are no signs announcing or advertising public transit at the state operating level. However, each of Tennessee's ninety-five counties has public transit, as does every major city in Tennessee. The sign below appears in the TDOT Design Manual:

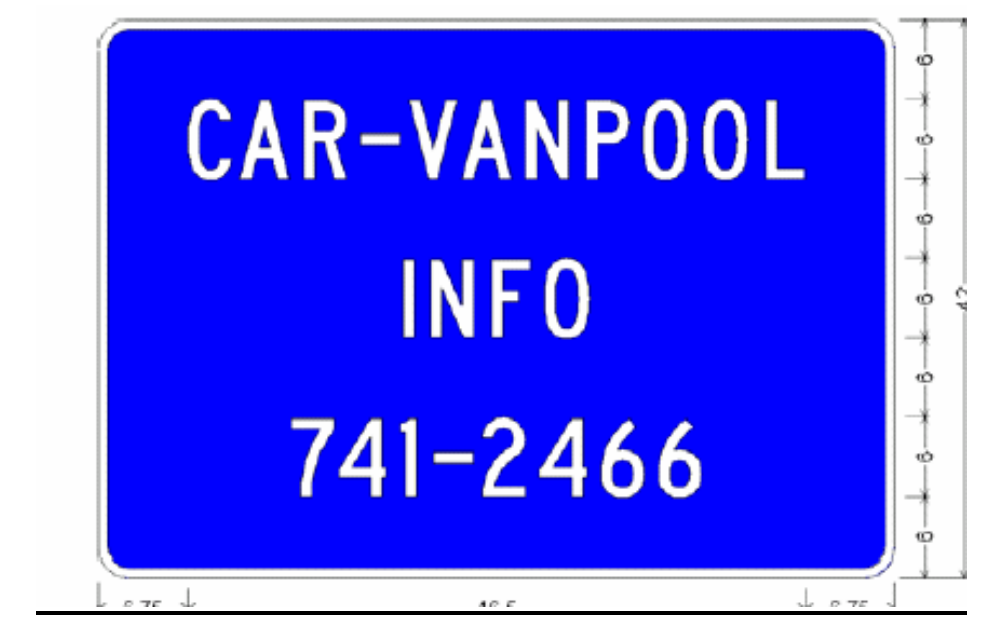




\section{Vermont}

The 511 signs include the 511 logo and the wording "travel info". These signs are similar to those used in South Dakota.
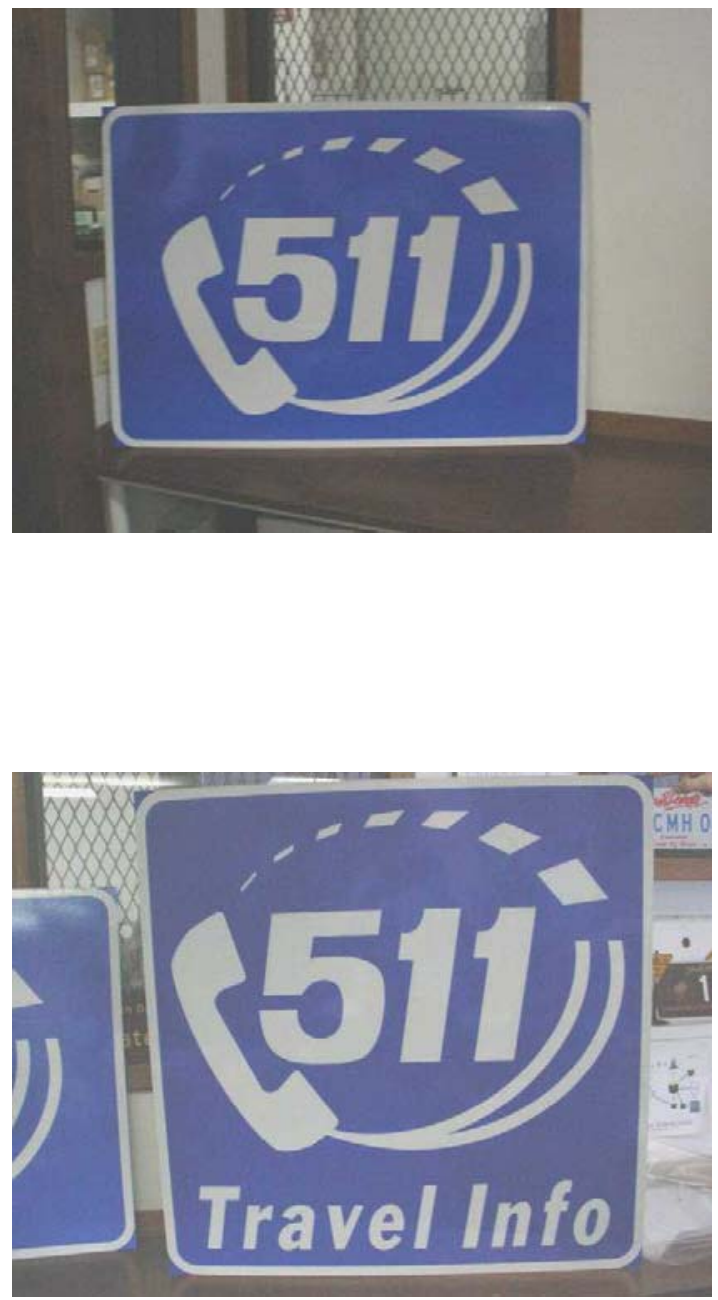


\section{Virginia}

This is the newest sign which incorporates the program logo. Others in the state simply list the name of the commuter program under the sign. Highway signs are a very effective way to get phone numbers out there for commuters in Virginia.

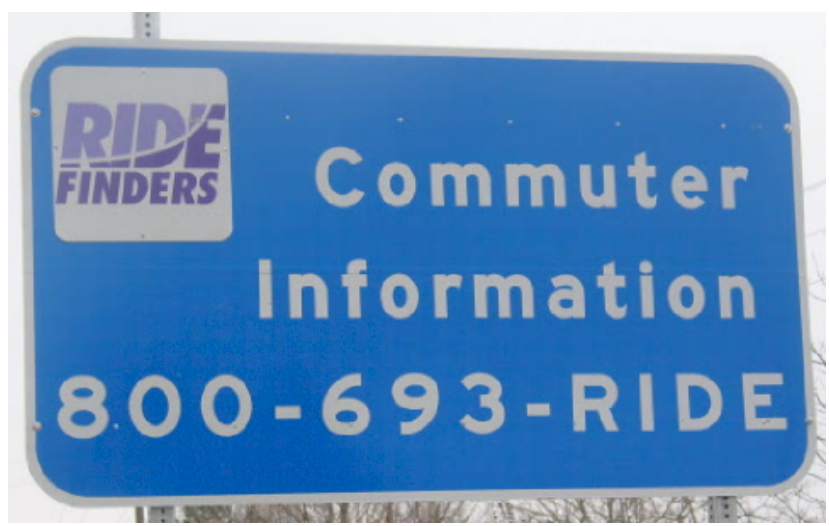




\section{$\underline{\text { West Virginia }}$}

At this time, West Virginia does not have carpool or transit programs that warrant such signing. Additionally, the West Virginia DOT has not identified "511 Information" as a priority to be implemented. As a result, no signing of this type exists or has yet been developed. 